\title{
Relationships between starch concentration of dry feed, diet digestibility, and growth of dairy calves up to 16 weeks of age
}

\author{
W. Hu, ${ }^{1}$ T. M. Hill, T. S. Dennis, F. X. Suarez-Mena, J. D. Quigley, J. R. Knapp, and R. L. Schlotterbeck \\ Nurture Research Center, Provimi, Cargill Premix and Nutrition, Brookville, $\mathrm{OH} 45309$
}

\section{ABSTRACT}

Our objective was to examine the potential relationship between starch concentration of dry feed and growth performance of young dairy calves via mixedeffects model analyses. A database was developed from 6 published studies conducted at the Nurture Research Center, Provimi (Brookville, OH), from 2008 to 2017 that included 18 dietary treatments and 372 calves at 0 to 8 wk of age in 5 nursery trials and 26 dietary treatments and 660 calves at 8 to 16 wk of age in 8 grower trials. The dry feeds ranged from 10.1 to $53.3 \%$ starch, 12.1 to $45.3 \%$ neutral detergent fiber, and 2.7 to $3.0 \mathrm{Mcal} / \mathrm{kg}$ of metabolizable energy [dry matter (DM) basis]. In all nursery trials, with increasing starch concentration in starter, average daily gain (ADG), hip width change, and starter intake linearly increased. In all grower trials, as starch concentration of dry feed increased, ADG, hip width change, and ADG/DM intake linearly increased; DM intake and DM intake/body weight were unaffected. In addition, the calves at 6 to 16 wk of age had greater digestibility of DM and crude protein with increasing starch concentration of dry feed. As indicated by meta-regression analysis, growth responses to starch concentration were influenced by metabolizable energy concentration in dry feed fed to the calves up to 16 wk of age. Changing starch from 23 to $43 \%$ on a DM basis (a typical range in the US industry) was predicted to increase ADG and hip width change by 5.8 and $5.0 \%$, respectively, for calves at 0 to 8 wk of age and by 9.6 and $11.2 \%$, respectively, for calves at 8 to $16 \mathrm{wk}$ of age. Positive linear relationships between starch concentration of dry feed with DM digestibility, ADG, and hip width change reflect the importance of starch in the diets of young dairy calves. Key words: performance, calf, starter, mixed-effects model

Received February 12, 2018.

Accepted March 28, 2018.

${ }^{1}$ Corresponding author: whu@provimi-na.com

\section{INTRODUCTION}

Young calves face tremendous physiological and metabolic challenges during the transition from milkfed preruminants to functional ruminants. Appropriate nutrition management for calves is thus essential in successful rearing programs for dairy producers. Dry (starter) feed consumption initiates and promotes rumen development. It is suggested that relatively high concentrations of readily fermentable carbohydrates adequate in digestible fiber should be included in starter diets to support fermentation necessary for proper ruminal tissue growth (NRC, 2001). In recent years, extensive research has been carried out to examine the effect of varying the source and content of carbohydrate and fiber in starter with addition of different sources and varying amounts of forage (Kosiorowska et al., 2011; Terré et al., 2013; Maktabi et al., 2016) on rumen development, health, and growth performance of calves with the aim of defining the solid feed feeding strategies for pre- or postweaning calves.

Starch supplied mostly by cereal grains represents a large fraction of calf starter diets. Readily fermentable starch in the starter diet fed to calves is fermented in the rumen to produce short-chain fatty acids and, consequently, stimulate rumen development (Kosiorowska et al., 2011). However, high starch intake might result in low rumen $\mathrm{pH}$ (Kristensen et al., 2007). Low rumen $\mathrm{pH}$ could further induce SARA. It has been reported that adding forage to starter diets improved rumen pH (Kim et al., 2016) and ADG of dairy calves (Terré et al., 2013). Nevertheless, increasing the amount of dietary NDF via addition of fiber in the starter diet, hay provision, or a combination of both would likely reduce the proportion of starch and energy concentration of the diets. This might be a reason why it has also been reported that added hay and cottonseed hulls reduced ADG of dairy calves (Hill et al., 2008a). So far, little information is available regarding the optimal starch concentration of dry feed for obtaining the best rumen development and growth performance. Analyses reported herein are based on data collated from the previous studies, conducted in Nurture Research Center, Provimi (Brookville, $\mathrm{OH}$ ), in which male Holstein 
calves were fed dry feed with different starch concentrations. The objective of this study was to examine potential relationships between starch concentration of dry feed and growth performance and nutrient digestibility of dairy calves.

\section{MATERIALS AND METHODS}

Calves used in all studies were cared for by acceptable practices as described in the previous or current editions of the Guide for the Care and Use of Agricultural Animals in Research and Teaching (FASS, 2010).

\section{Database}

Data used to examine the potential relationships between starch concentration of dry feed and other variables were collected from the published studies (Hill et al. 2008a,b, 2012, 2016; Suarez-Mena et al., 2011; Dennis et al., 2017), which were conducted at the Nurture Research Center, Provimi, located in southwest Ohio, from 2008 to 2017. The database consisted of 3 subdata sets: (1) nursery (0-8 wk of age; 5 trials including 18 dietary treatments), (2) grower (calves 8-16 wk of age; 8 trials including 26 dietary treatments), and (3) digestibility [nutrient digestibility measured in postweaned calves at $6-16$ wk of age (trial 1 in Suarez-Mena et al., 2011) and grower at 8 to 16 wk of age (Hill et al., 2016)]. Across all trials, results reported the effect of varying starch concentration in calf starter either alone or blended with chopped grass hay (Table 1).

All calves were Holstein males initially less than 1 wk of age and were housed in $1.2 \mathrm{~m} \times 2.4 \mathrm{~m}$ individual pens in a curtain-sided, naturally ventilated barn with no added heat. The pens were separated by wire-mesh panels, and the coarse rock, tile-drained floor was bedded with straw. Milk replacer was diluted with water to 12 to $15 \%$ (g/L) DM before feeding. Milk replacer was fed to the nursery calves at a rate of $0.454 \mathrm{~kg} / \mathrm{d}$ (Hill et al., 2008b) or $0.681 \mathrm{~kg} / \mathrm{d}$ (Hill et al., 2008a; SuarezMena et al., 2011) on an as-fed basis, divided equally into a.m. and p.m. feedings for $25 \mathrm{~d}$ followed by only the a.m. feeding (once daily, in the morning) at half the total daily amount of the previous milk replacer on $\mathrm{d} 26$ to 28. However, 2 rates of milk replacer (as-fed basis) were fed to the nursery calves in the study of Dennis et al. (2017): (1) $0.66 \mathrm{~kg}$ of DM fed in equal amounts twice daily (a.m. and p.m. feeding) for $39 \mathrm{~d}$ followed by 0.33 $\mathrm{kg}$ of DM fed once daily (a.m. feeding) for $3 \mathrm{~d}$; and (2) $0.87 \mathrm{~kg}$ of DM for $5 \mathrm{~d}$ and $1.08 \mathrm{~kg}$ of $\mathrm{DM}$ for $37 \mathrm{~d}$ fed in equal amounts twice daily and then $0.43 \mathrm{~kg}$ of DM fed once daily (a.m. feeding) for $7 \mathrm{~d}$. Starter and water were offered for ad libitum intake throughout the nurs- ery trial. For all grower trials, calves were randomly assigned to pens with approximately $6.5 \mathrm{~m}^{2}$ of outside pen space and 0.9 to $1.35 \mathrm{~m}^{2}$ of inside pen space per calf. Inside pen space was bedded with straw, and there was no added heat. Pen size varied, with 4 calves per pen in some trials (Hill et al., 2012, 2016; Dennis et al., 2017 ) but 6 calves per pen in the others (Hill et al., 2008a,b; Suarez-Mena et al., 2011). In the grower trials, calves were fed starter either alone or blended with chopped grass hay (Table 1) for ad libitum intake with unrestricted access to water. Detailed management practices, including vaccines or specific treatment applications in each individual trial, could be found in the original studies (Table 1). Mean, standard deviation, and minimal and maximal values for all major selected variables are in Table 2 .

\section{Statistical Analysis}

In all trials, treatment means of ADG, hip width change, and other dependent variables were used to examine the overall effects of varying starch concentrations across all trials in each of 3 subdata sets. There were several studies (Hill et al., 2012, 2016; Dennis et al., 2017) in which most of the trials were conducted in an experimental design with factorial arrangement of treatments (Table 1). Based on the treatment structure in those trials, an independent comparison of dietary treatments was constructed. Each comparison was considered specifically as a "trial" being included in the statistical model for further analysis, which would be the most appropriate way to detect true response resulting only from varying starch concentration in the diets. Potential relationships between dependent variables such as ADG and starch concentration in dry feed were examined among trials in each of 3 subdata sets using the PROC MIXED model in SAS (SAS Institute Inc., 2012). The model was

$$
\mathrm{Y}_{\mathrm{ij}}=\mathrm{B}_{0}+\mathrm{B}_{1} \mathrm{X}_{\mathrm{ij}}+\mathrm{s}_{\mathrm{i}}+\mathrm{b}_{1 \mathrm{i}} \mathrm{X}_{\mathrm{ij}}+\mathrm{e}_{\mathrm{ij}},
$$

where $\mathrm{i}$ is the $1,2, \ldots$, trials; $\mathrm{j}$ is the $1,2, \ldots, \mathrm{n}_{\mathrm{i}}$ observations within trial $\mathrm{i} ; \mathrm{B}_{0}$ is the overall intercept among trials (fixed effect); $\mathrm{B}_{1}$ is the slope of $\mathrm{Y}$ on $\mathrm{X}$ among trials (fixed effect); $\mathrm{X}_{\mathrm{ij}}$ is the value of variable $\mathrm{X}$ for the jth observation in trial $\mathrm{i}$; $\mathrm{s}_{\mathrm{i}}$ is the random intercept effect of trial $i ; b_{1 i}$ is the random slope effect of $\mathrm{Y}$ on $\mathrm{X}$ in trial $\mathrm{i}$; and $\mathrm{e}_{\mathrm{ij}}$ is the error term, assumed to be $N\left(0, \sigma^{2}\right)$. Trial was considered to be a random effect (St-Pierre, 2001), and significance was declared at $P<0.05$.

In the mixed-effects model, there are both fixed (intercept and slope) and random (intercept and slope) 
STARCH CONCENTRATION IN CALF STARTERS

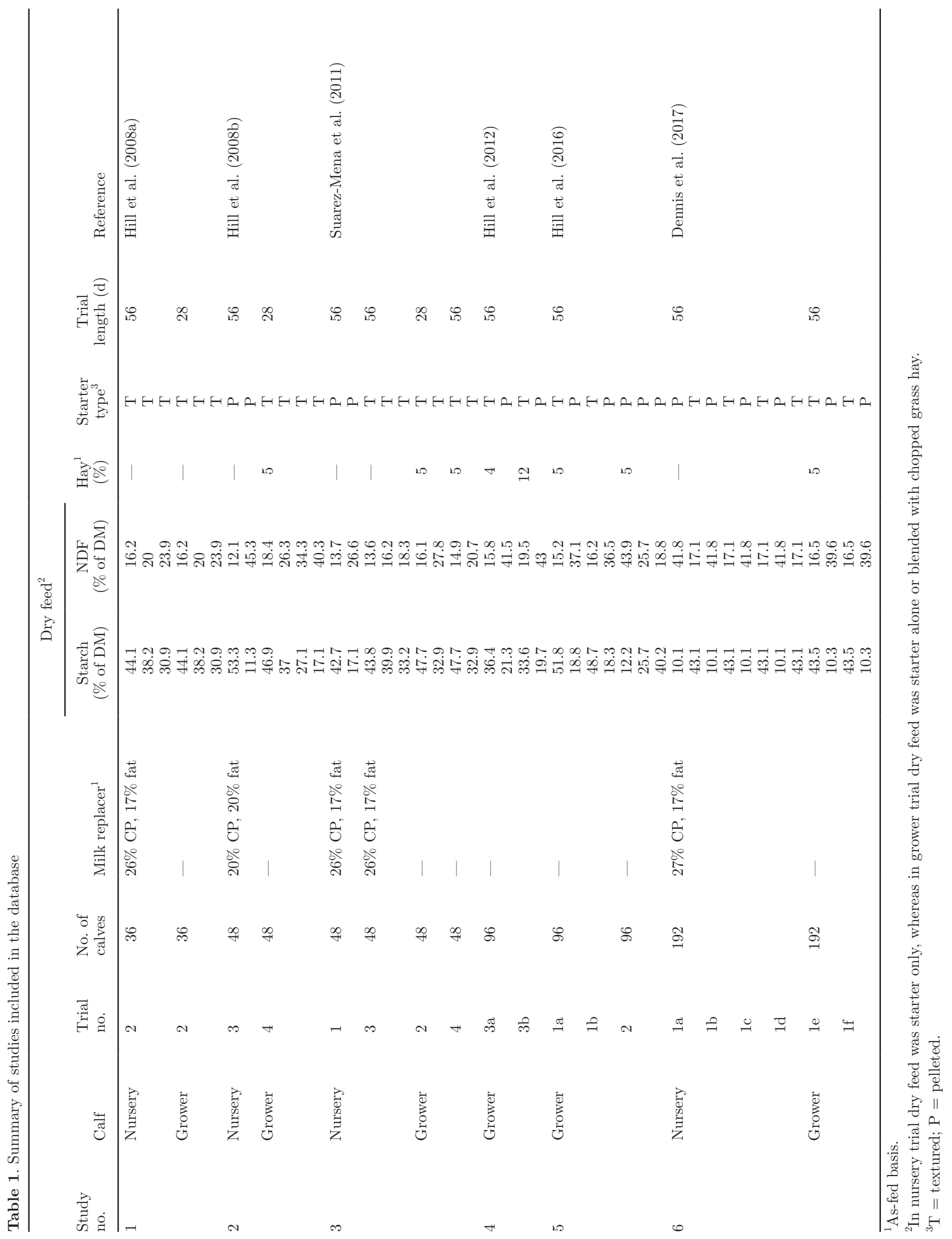


effects for independent variables. The intercept and slope of the fixed effect in the mixed model represent a mean intercept and a mean slope for the response such as ADG and so on to starch concentration of dry feed. Regression lines are presented based on predicted values of $\mathrm{ADG}$ or other dependent variables versus starch concentration, whereas adjusted observations among trials are also plotted to indicate trends of ADG or other dependent variables versus starch concentration. The random trial effect represents the variance among trials not accounted for by other variables in the model that had been shown to be important in regression analysis (St-Pierre, 2001). When presenting results of mixed-model analyses graphically in 2 dimensions, $\mathrm{Y}$ observations must be adjusted for the additional $\mathrm{i}$ (number of trials in each of 3 subdata sets) dimensions represented by individual trials. Adjusted observations for trial effects were also used to calculate coefficients of determination $\left(\mathrm{R}^{2}\right)$ according to St-Pierre (2001).

Meta-regression was conducted using the mixedeffects model in each of 2 subdata sets (nursery and grower data sets) including all trials to investigate dietary factors that might influence growth performance and nutrient digestibility responses. This was done by screening individual dietary factors using a $P$-value of $\leq 0.20$. Retained factors were then subjected to backward stepwise meta-regression until all remaining factors achieved a significant level of $<0.05$ (Rabiee et al., 2012). The major dietary factors evaluated were milk replacer feeding rate; contents of $\mathrm{ME}$ (Mcal $/ \mathrm{kg}$ ), $\mathrm{CP}$ (\% of DM), and fat (\% of DM) in milk replacer; and contents of ME (Mcal $/ \mathrm{kg}), \mathrm{CP}$ (\% of DM), fat (\% of DM), and NDF (\% of DM) in dry feed. No factors related to milk replacer were involved in the analysis for grower data set.

\section{RESULTS}

\section{Characteristics of the Database}

Table 1 provides a summary of the studies in the database, which included 1,032 Holstein male dairy calves (372 in nursery and 660 in grower trials). Milk replacer varied among nursery trials, with contents of protein and fat in the milk replacers ranging from 20 to $27 \%$ and 17 to $20 \%$ on an as-fed basis, respectively

Table 2. Mean and range of starch concentration of dry feed and selected variables in the database

\begin{tabular}{|c|c|c|c|c|c|}
\hline Variable & No. & Mean & $\mathrm{SD}$ & Minimum & Maximum \\
\hline \multicolumn{6}{|l|}{ Nursery } \\
\hline Starch in starter (\% of DM) & 18 & 31.52 & 15.37 & 10.10 & 53.30 \\
\hline $\mathrm{CP}$ in starter $(\%$ of $\mathrm{DM})$ & 18 & 20.88 & 0.76 & 20.20 & 22.20 \\
\hline NDF in starter ( $\%$ of DM) & 18 & 24.53 & 11.98 & 12.10 & 45.30 \\
\hline Fat in starter $(\%$ of DM) & 18 & 3.98 & 0.89 & 3.10 & 7.00 \\
\hline ME in $\operatorname{starter}^{1}(\mathrm{Mcal} / \mathrm{kg}$ of DM) & 18 & 2.94 & 0.06 & 2.85 & 3.03 \\
\hline NDF in starter $(\%$ of $\mathrm{DM})$ & 18 & 24.53 & 11.98 & 12.10 & 45.30 \\
\hline Initial BW $(\mathrm{kg})$ & 18 & 43.21 & 1.77 & 40.47 & 47.10 \\
\hline Initial hip width (cm) & 18 & 17.57 & 0.20 & 17.05 & 18.00 \\
\hline ADG $(\mathrm{kg} / \mathrm{d})$ & 18 & 0.53 & 0.08 & 0.37 & 0.65 \\
\hline Starter intake $(\mathrm{kg} / \mathrm{d})$ & 18 & 0.70 & 0.26 & 0.35 & 1.18 \\
\hline $\mathrm{DMI}(\mathrm{kg} / \mathrm{d})$ & 18 & 1.16 & 0.19 & 0.79 & 1.49 \\
\hline DMI/BW (kg/kg) & 18 & 1.22 & 0.42 & 0.60 & 1.96 \\
\hline ADG/DMI $(\mathrm{kg} / \mathrm{kg})$ & 18 & 0.46 & 0.11 & 0.27 & 0.75 \\
\hline Hip width change $(\mathrm{cm} / \mathrm{d})$ & 18 & 0.064 & 0.007 & 0.048 & 0.075 \\
\hline \multicolumn{6}{|l|}{ Grower } \\
\hline Starch in dry feed (\% of DM) & 26 & 32.19 & 12.95 & 10.30 & 51.76 \\
\hline $\mathrm{CP}$ in dry feed (\% of DM) & 26 & 19.57 & 1.27 & 17.19 & 21.38 \\
\hline NDF in dry feed (\% of DM) & 26 & 26.32 & 10.51 & 14.89 & 43.94 \\
\hline Fat in dry feed (\% of DM) & 26 & 4.28 & 0.82 & 3.16 & 6.11 \\
\hline ME in dry feed ${ }^{1}$ (Mcal/kg of DM) & 26 & 2.84 & 0.08 & 2.70 & 2.98 \\
\hline Initial BW $(\mathrm{kg})$ & 26 & 73.62 & 2.89 & 66.20 & 77.90 \\
\hline Initial hip width (cm) & 26 & 21.36 & 0.38 & 20.40 & 21.90 \\
\hline ADG $(\mathrm{kg} / \mathrm{d})$ & 26 & 1.04 & 0.15 & 0.80 & 1.33 \\
\hline DMI $(\mathrm{kg} / \mathrm{d})$ & 26 & 2.91 & 0.37 & 2.24 & 3.52 \\
\hline DMI/BW (kg/kg) & 26 & 3.03 & 0.32 & 2.48 & 3.71 \\
\hline ADG/DMI (kg/kg) & 26 & 0.36 & 0.05 & 0.29 & 0.46 \\
\hline \multicolumn{6}{|l|}{ Digestibility } \\
\hline DM (\%) & 9 & 79.39 & 5.40 & 67.60 & 85.20 \\
\hline $\mathrm{CP}(\%)$ & 9 & 77.64 & 8.16 & 63.90 & 84.90 \\
\hline NDF (\%) & 7 & 64.01 & 5.76 & 56.10 & 70.70 \\
\hline Fat $(\%)$ & 9 & 83.98 & 6.33 & 68.50 & 89.60 \\
\hline Starch (\%) & 7 & 97.43 & 1.57 & 95.10 & 99.00 \\
\hline
\end{tabular}

${ }^{1}$ Calculated using equations in NRC (2001). 
(Table 2). The contents of starch, NDF, and ME in the starters in the nursery trials ranged from 10.1 to $53.3 \%, 12.1$ to $45.3 \%$, and 2.85 to $3.03 \mathrm{Mcal} / \mathrm{kg}$ of DM, respectively, whereas the contents of starch, NDF, and $\mathrm{ME}$ in the dry feeds in the grower trials ranged from 10.3 to $51.8 \%, 14.9$ to $43.9 \%$, and 2.70 to $2.98 \mathrm{Mcal} / \mathrm{kg}$ of DM, respectively (Table 2).

\section{Growth Performance Responses}

In all nursery trials, ADG increased linearly $(P=$ $\left.0.010 ; \mathrm{R}^{2}=0.56\right)$ with increasing starch concentration (Table 3; Figure 1). Also, the calves had greater hip width change (Figure 2; linear, $P=0.006 ; \mathrm{R}^{2}=0.61$ ) with increasing starch concentration. As starch concentration in starter increased, a linear effect on starter intake $\left(P=0.012 ; \mathrm{R}^{2}=0.55\right)$, DMI $\left(P=0.014 ; \mathrm{R}^{2}=\right.$ $0.54)$, and DMI/BW $\left(P=0.029 ; \mathrm{R}^{2}=0.46\right)$ was observed (Table 3). However, ADG/DMI was unaffected by starch concentration in calf starter (Table 3). Metaregression analysis (Table 4) in all nursery trials showed that ME concentration in starter had positive effects on the effect of starch concentration on ADG $(P=0.006)$ and hip width change $(P=0.019)$, whereas fat concentration in starter $(P=0.040)$ negatively influenced the hip width change response to starch concentration. In addition, ME concentration in starter had positive effects on starter intake $(P=0.010)$ and $\mathrm{DMI} / \mathrm{BW}(P$ $=0.029)$, whereas milk replacer feeding rate had negative effects on starter intake $(P=0.032)$ and $\mathrm{DMI} / \mathrm{BW}$ $(P=0.012)$. No factor from the proposed dietary factor list was identified in meta-regression analysis that influenced the effect of starch concentration on ADG/ DMI.

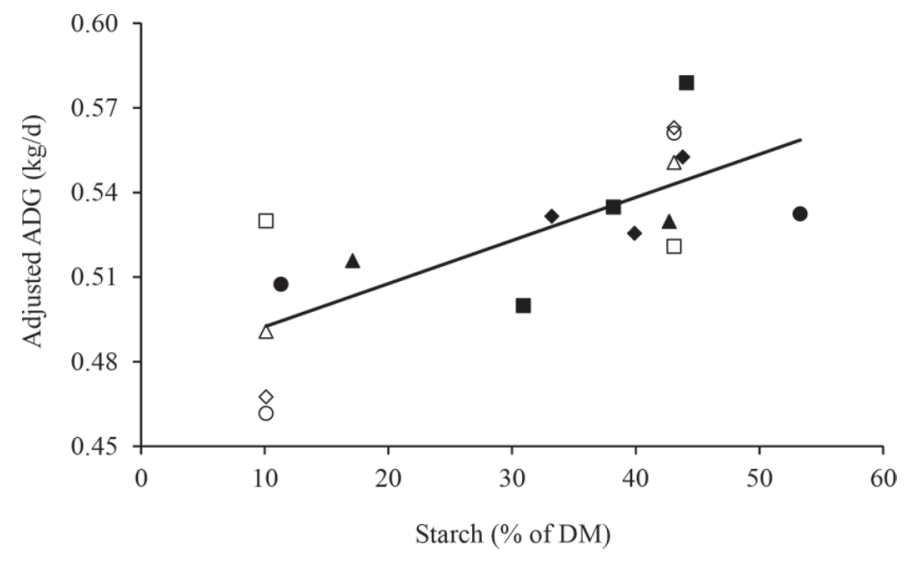

Figure 1. Relationship between starch concentration in starter and adjusted ADG for all calves in nursery trials. The adjusted ADG $(\mathrm{kg} / \mathrm{d})=0.00153 \times \operatorname{starch}(\%)+0.477 ;$ across trials, linear $P=0.010 ;$ $\mathrm{R}^{2}=0.56 ; \mathrm{n}=18$. Legend: Hill et al. (2008a) (ם), Hill et al. (2008b) (•), Suarez-Mena et al. (2011) trial 1 (ム), Suarez-Mena et al. (2011) trial $3(\diamond)$, Dennis et al. (2017) trial 1a $(\diamond)$, Dennis et al. (2017) trial 1b ( $\square$ ), Dennis et al. (2017) trial 1c (○), and Dennis et al. (2017) trial $1 \mathrm{~d}(\Delta)$.

In all grower trials, ADG increased linearly $(P<$ $\left.0.001 ; \mathrm{R}^{2}=0.68\right)$ with increasing starch concentration (Table 3; Figure 3). Also, the calves had greater hip width change (Figure 4; linear, $P<0.001 ; \mathrm{R}^{2}=0.75$ ) with increasing starch concentration. Dry matter intake and DMI/BW were unaffected by starch concentration (Table 3). However, ADG/DMI increased linearly $(P<$ $\left.0.001 ; \mathrm{R}^{2}=0.83\right)$ as starch concentration of dry feed increased (Table 3). Meta-regression analysis (Table 4) in all grower trials showed that NDF content in dry feed had negative effects on the effect of starch concentration of dry feed on ADG $(P<0.001)$ and hip

Table 3. Regression relationships to starch concentration of dry feed inferred using mixed-effects models

\begin{tabular}{|c|c|c|c|c|c|c|c|c|c|}
\hline Variable & No. & Intercept & $\mathrm{SE}$ & $P$-value & Linear & $\mathrm{SE}$ & $P$-value & Residual SE & $\mathrm{R}^{2}$ \\
\hline $\operatorname{ADG}(\mathrm{kg} / \mathrm{d})$ & 18 & 0.477 & 0.031 & $<0.001$ & 0.00153 & 0.00047 & 0.010 & 0.00037 & 0.56 \\
\hline Starter intake $(\mathrm{kg} / \mathrm{d})$ & 18 & 0.601 & 0.089 & $<0.001$ & 0.00219 & 0.00070 & 0.012 & 0.00083 & 0.55 \\
\hline DMI/BW $(\mathrm{kg} / \mathrm{kg})$ & 18 & 1.067 & 0.148 & $<0.001$ & 0.00308 & 0.00118 & 0.029 & 0.00233 & 0.46 \\
\hline ADG/DMI $(\mathrm{kg} / \mathrm{kg})$ & 18 & 0.447 & 0.044 & $<0.001$ & 0.00042 & 0.00027 & 0.159 & 0.00012 & 0.23 \\
\hline Hip width change $(\mathrm{cm} / \mathrm{d})$ & 18 & 0.059 & 0.003 & $<0.001$ & 0.00016 & 0.00004 & 0.006 & 0.000003 & 0.61 \\
\hline DMI $(\mathrm{kg} / \mathrm{d})$ & 26 & 2.842 & 0.136 & $<0.001$ & 0.00127 & 0.00229 & 0.588 & 0.00705 & 0.02 \\
\hline DMI/BW $(\mathrm{kg} / \mathrm{kg})$ & 26 & 3.047 & 0.110 & $<0.001$ & -0.00180 & 0.00160 & 0.281 & 0.00342 & 0.09 \\
\hline $\mathrm{ADG} / \mathrm{DMI}(\mathrm{kg} / \mathrm{kg})$ & 26 & 0.313 & 0.015 & $<0.001$ & 0.00139 & 0.00018 & $<0.001$ & 0.00004 & 0.83 \\
\hline Hip width change $(\mathrm{cm} / \mathrm{d})$ & 26 & 0.077 & 0.003 & $<0.001$ & 0.00055 & 0.00008 & $<0.001$ & 0.000010 & 0.75 \\
\hline \multicolumn{10}{|l|}{ Digestibility } \\
\hline DM $(\%)$ & 9 & 71.66 & 2.62 & $<0.001$ & 0.2452 & 0.0554 & 0.012 & 3.792 & 0.82 \\
\hline $\mathrm{CP}(\%)$ & 9 & 72.31 & 4.50 & $<0.001$ & 0.1576 & 0.0382 & 0.015 & 1.779 & 0.82 \\
\hline
\end{tabular}


Table 4. Summary of meta-regression factor influencing the response to dietary starch concentration

\begin{tabular}{|c|c|c|c|}
\hline Variable & Estimate & $\mathrm{SE}$ & $P$-value \\
\hline \multicolumn{4}{|l|}{ Nursery } \\
\hline \multicolumn{4}{|l|}{$\operatorname{ADG}(\mathrm{kg} / \mathrm{d})$} \\
\hline Intercept & -0.842 & 0.387 & 0.066 \\
\hline ME in starter (Mcal/kg) & 0.466 & 0.132 & 0.006 \\
\hline \multicolumn{4}{|l|}{ Hip width change $(\mathrm{cm} / \mathrm{d})$} \\
\hline Intercept & -0.0309 & 0.0356 & 0.415 \\
\hline Fat in starter (\% of DM) & -0.0019 & 0.0008 & 0.040 \\
\hline $\mathrm{ME}$ in starter $(\mathrm{Mcal} / \mathrm{kg})$ & 0.0348 & 0.0118 & 0.019 \\
\hline \multicolumn{4}{|l|}{ Starter intake $(\mathrm{kg} / \mathrm{d})$} \\
\hline Intercept & -0.970 & 0.628 & 0.173 \\
\hline $\begin{array}{l}\text { Milk replacer feeding rate } \\
(\mathrm{kg} / \mathrm{d})\end{array}$ & -0.676 & 0.266 & 0.032 \\
\hline $\mathrm{ME}$ in starter (Mcal/kg) & 0.668 & 0.205 & 0.010 \\
\hline $\mathrm{ADG} / \mathrm{DMI}(\mathrm{kg} / \mathrm{kg})$ & $\mathrm{ND}^{1}$ & & \\
\hline \multicolumn{4}{|l|}{$\mathrm{DMI} / \mathrm{BW}(\mathrm{kg} / \mathrm{kg})$} \\
\hline Intercept & -0.937 & 1.076 & 0.418 \\
\hline $\begin{array}{l}\text { Milk replacer feeding rate } \\
(\mathrm{kg} / \mathrm{d})\end{array}$ & -1.251 & 0.397 & 0.012 \\
\hline $\mathrm{ME}$ in starter (Mcal/kg) & 0.918 & 0.354 & 0.029 \\
\hline \multicolumn{4}{|l|}{ Grower } \\
\hline \multicolumn{4}{|l|}{$\operatorname{ADG}(\mathrm{kg} / \mathrm{d})$} \\
\hline Intercept & 1.175 & 0.048 & $<0.001$ \\
\hline NDF in dry feed ( $\%$ of DM) & -0.006 & 0.001 & $<0.001$ \\
\hline \multicolumn{4}{|l|}{ Hip width change $(\mathrm{cm} / \mathrm{d})$} \\
\hline Intercept & 0.1108 & 0.0039 & $<0.001$ \\
\hline NDF in dry feed ( $\%$ of DM) & -0.0006 & 0.0001 & $<0.001$ \\
\hline DMI $(\mathrm{kg} / \mathrm{d})$ & ND & & \\
\hline \multicolumn{4}{|l|}{ ADG/DMI $(\mathrm{kg} / \mathrm{kg})$} \\
\hline Intercept & 0.429 & 0.033 & $<0.001$ \\
\hline Fat in dry feed (\% of DM) & -0.017 & 0.007 & 0.039 \\
\hline DMI/BW $(\mathrm{kg} / \mathrm{kg})$ & ND & & \\
\hline
\end{tabular}

${ }^{1} \mathrm{ND}=$ no factor was determined at $P<0.05$.

width change $(P<0.001)$. In addition, it was found that ADG/DMI was affected negatively by dietary fat content $(P=0.039)$. No factor from the proposed di-

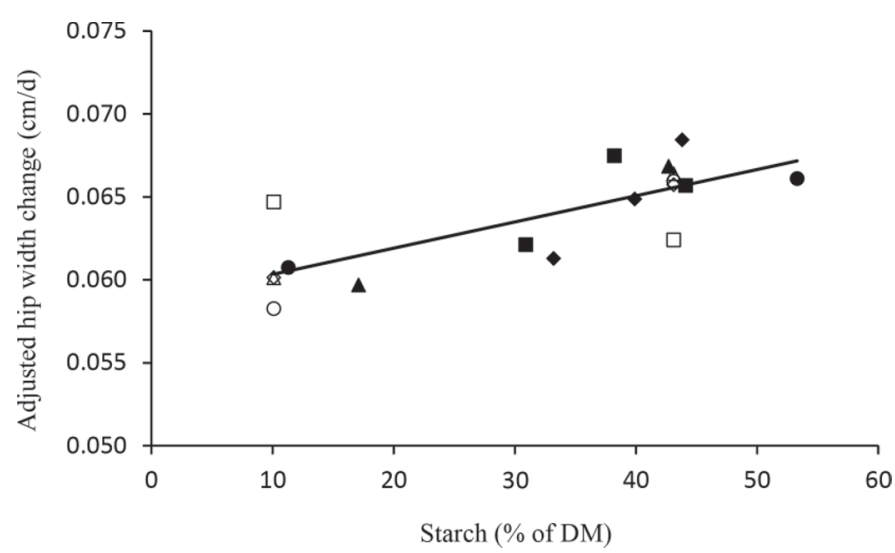

Figure 2. Relationship between starch concentration in starter and adjusted hip width change for all calves in nursery trials. The adjusted hip width change $(\mathrm{cm} / \mathrm{d})=0.00016 \times$ starch $(\%)+0.059$; across trials, linear $P=0.006 ; \mathrm{R}^{2}=0.61 ; \mathrm{n}=18$. Legend: Hill et al. (2008a)

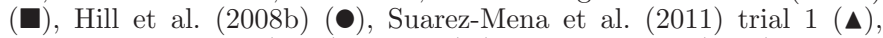
Suarez-Mena et al. (2011) trial 3 ( ), Dennis et al. (2017) trial 1a $(\diamond)$, Dennis et al. (2017) trial 1b ( $\square)$, Dennis et al. (2017) trial 1c (○), Dennis et al. (2017) trial $1 \mathrm{~d}(\Delta)$.

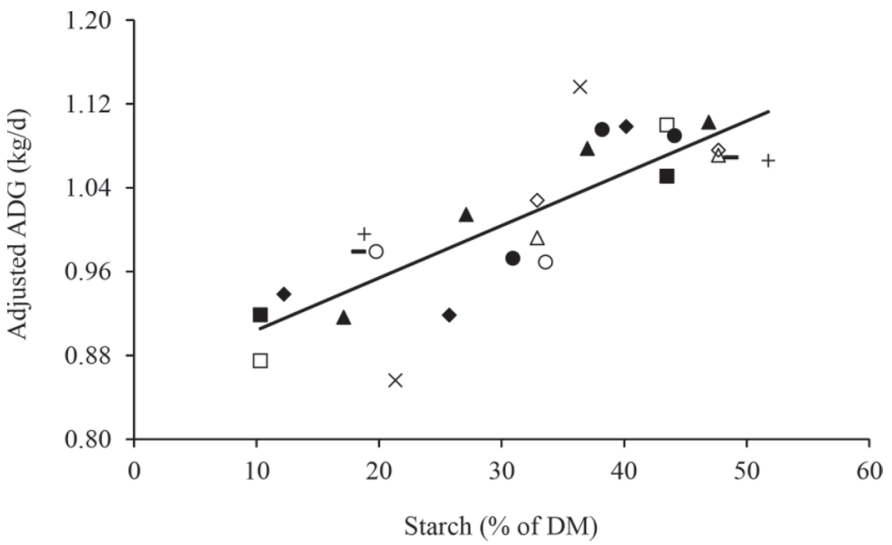

Figure 3. Relationship between starch concentrations of dry feed and adjusted ADG for all calves in grower trials. The adjusted ADG $(\mathrm{kg} / \mathrm{d})=0.00499 \times \operatorname{starch}(\%)+0.854 ;$ across trials, linear $P<0.001$; $\mathrm{R}^{2}=0.68 ; \mathrm{n}=26$. Legend: Hill et al. (2008a) $(\bullet)$, Hill et al. (2008b) (ム), Hill et al. (2012) trial 3a $(\times)$, Hill et al. (2012) trial 3b (O), Hill et al. (2016) trial 1a (+), Hill et al. (2016) trial 1b (-), Hill et al. $(2016)$ trial $2(\bullet)$, Suarez-Mena et al. (2011) trial $2(\Delta)$, Suarez-Mena et al. (2011) trial $4(\diamond)$, Dennis et al. (2017) trial 1e (ם), Dennis et al. (2017) trial 1f $(\square)$.

etary factor list was identified in meta-regression analysis that influenced the effect of starch concentration on DMI and DMI/BW.

\section{Digestibility Response}

As starch concentration of dry feed increased (Table 3 ), calves at 6 to 16 wk of age had greater digestibility of DM (Figure 5; linear, $P=0.012 ; \mathrm{R}^{2}=0.82$ ) and

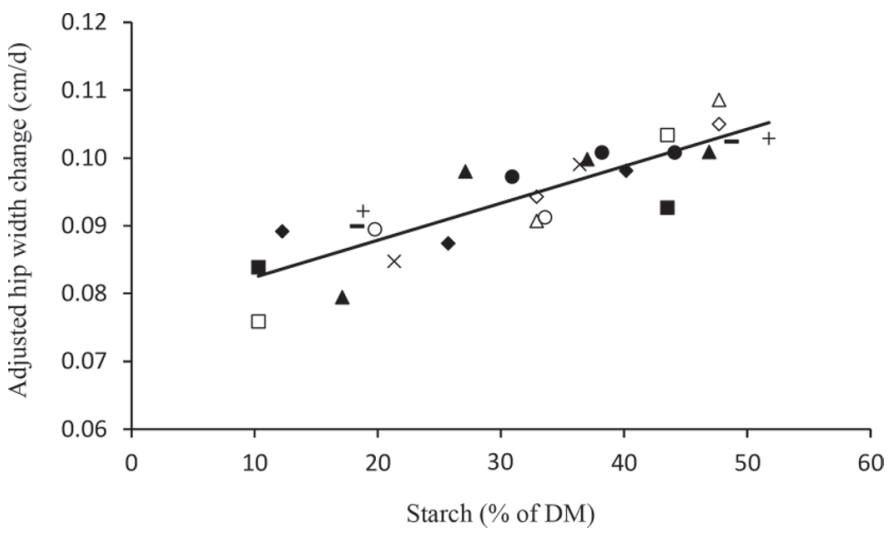

Figure 4. Relationship between starch concentrations of dry feed and adjusted hip width change for all calves in grower trials. The adjusted hip width change $(\mathrm{cm} / \mathrm{d})=0.00055 \times \operatorname{starch}(\%)+0.077$; across trials, linear $P<0.001 ; \mathrm{R}^{2}=0.75 ; \mathrm{n}=26$. Legend: Hill et al.

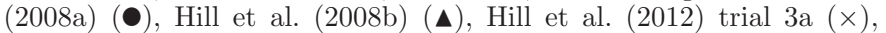
Hill et al. (2012) trial 3b (○), Hill et al. (2016) trial 1a (+), Hill et al. (2016) trial 1b (-), Hill et al. (2016) trial $2(\checkmark)$, Suarez-Mena et al. $(2011)$ trial $2(\Delta)$, Suarez-Mena et al. (2011) trial $4(\diamond)$, Dennis et al.

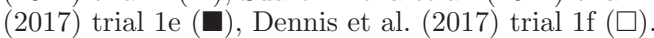




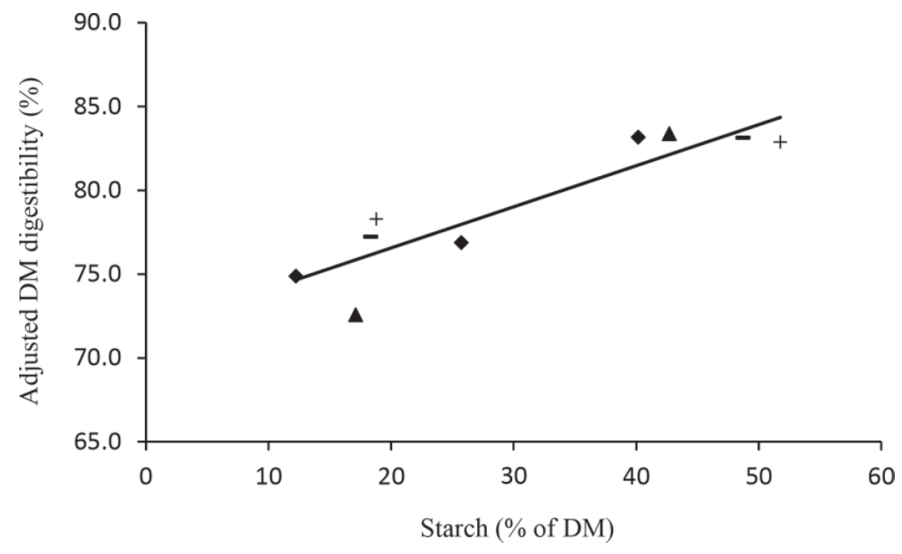

Figure 5. Relationship between starch concentrations of dry feed and adjusted DM digestibility for all calves at 6 to $16 \mathrm{wk}$ of age. The adjusted DM digestibility $(\%)=0.2452 \times \operatorname{starch}(\%)+71.66$; across trials, linear $P=0.012 ; \mathrm{R}^{2}=0.82 ; \mathrm{n}=9$. Legend: Hill et al. (2016) trial 1a (+), Hill et al. (2016) trial 1b (-), Hill et al. (2016) trial $2(\diamond)$, Suarez-Mena et al. (2011) trial 1 (ム).

CP (linear, $P=0.015 ; \mathrm{R}^{2}=0.82$ ), but starch was less digested (linear, $P=0.033 ; \mathrm{R}^{2}=0.74$ ). Dietary starch concentration did not affect the digestibility of NDF or fat in dry feed (Table 3).

\section{DISCUSSION}

Straw bedding is a proper and critical management practice that promotes health and growth of calves in all seasons (Lago et al., 2006; Hill et al., 2007, 2011). Straw bedding was used in all trials. However, Kertz (2007) suggested that the confounding effects could be obtained for the calves fed pelleted starter caused by access to straw from bedding. Pelleted or high-starch diets might lead to calves sorting for physically effective fiber or consuming straw from bedding, and straw consumption from bedding or sorting could affect calf growth and digestion. In all trials, new bedding was not added just before or during fecal collection periods for estimation of digestibility to minimize the chance of straw intake. Fokkink et al. (2011) showed that straw intake was a very small proportion of total intake for calves housed without straw bedding and did not differ between calves fed high- and low-starch diets. In the absence of a proper method to make an adjustment, the amount of straw from bedding that might have been consumed, sorting, and their potential effects on calf growth performance and digestion were not considered in the current study.

Relationships between starch concentration of dry feed and growth performance of Holstein male calves were examined. Results clearly demonstrated that increasing starch concentration of dry feed not only improved ADG but also increased frame size in Holstein male calves up to 16 wk of age. Lammers et al. (1998) showed that in calves from birth through 6 wk of age, the ADG was highly correlated with total starter intake $\left(\mathrm{R}^{2}=0.73\right)$. Moreover, intake of calf starter has been identified through multiple regression analysis as one of the most important factors affecting calf growth and hip width change up to 8 wk of age (Bateman et al., 2012). Therefore, in the nursery trials of the current study, at least part of the increase in ADG and frame size could be ascribed to the increase in starter intake resulting from increasing starch concentration in the starter. With increasing starch concentration, the digestibility of DM increased linearly. As a result, more nutrients would be expected to be available to support calf growth.

As a calf transitions from a preruminant to functional ruminant, the rumen needs to develop sufficient physical capacity and absorptive surface area to utilize solid feed effectively. Calf starter plays a critical role in rumen development during the transition. The ingestion of solid feed stimulates rumen microbial proliferation and produces VFA via microbial fermentation. Resultant VFA, especially butyrate, are required for development of the rumen papillae. Digestion of starch in starter is the primary source of butyrate in the rumen. Zitnan et al. (1998) showed that a high-starch diet in the early weaning period of calves increased the surface of the rumen epithelium. It is reasonable to postulate that with increasing starch concentration, more butyrate would be produced from microbial fermentation and the rumen would be better developed; then, improved rumen function could in turn drive the calf to eat more starter. Nevertheless, in grower trials, as starch concentration of dry feed increased, DMI and DMI/BW were unchanged. Because of unaffected DMI with increasing starch concentration of dry feed for calves at 8 to $16 \mathrm{wk}$ of age, the effect of starch concentration on ADG/DMI primarily resulted from its effect on ADG.

It should be noted that in the current study, when the effect of varying starch concentration of dry feed on calf growth performance was assessed, multiple dietary factors could influence the observed relationships and should be taken into consideration. Those factors, including milk replacer feeding rate, nutrient and ingredient compositions, and physical forms, might exert effects either alone or in combination on various responses observed. Attempts have been made to identify one or more of the factors influencing the effect of starch concentration on growth performance of calves. It was not surprising, as others have indicated (Khan et al., 2011), that increasing milk replacer feeding rate would decrease starter intake in nursery calves (Table 4). Moreover, the meta-regression analysis indicated that the ME content of the starter in nursery trials 
was associated positively with ADG and frame growth, whereas NDF content in dry feed in the grower trials was associated negatively with ADG and frame growth (Table 4). As expected, the starch concentration of dry feed in the current study was found to be associated with $\mathrm{ME}$ concentration $\left(\mathrm{R}^{2}=0.78 ; P<0.001\right)$ but associated inversely with NDF content $\left(\mathrm{R}^{2}=0.92 ; P\right.$ $<0.001)$. With increasing starch concentration, the digestion of more starch would increase the energy supply for growth. In contrast, high NDF content in dry feed would reduce the energy supply to calves. Nevertheless, inclusion of a small amount of forage in the diet of young calves could be beneficial. Castells et al. (2013) suggested that rumen $\mathrm{pH}$ would increase when consumption of forage is about $4 \%$ of total solid feed intake, as occurred in their study when the calves were offered chopped oat hay. The improvement in rumen environment would then allow greater intake of solid feed and, consequently, an improvement of growth performance. Hill et al. (2010) reported that up to $3 \%$ roughage NDF maximized intake in the calves at 8 to 16 wk of age, whereas ADG peaked at approximately $1.5 \%$ roughage NDF. Thus, the optimum amount of forage for maximizing ADG in young calves is likely less than $3 \%$ forage NDF.

Starch concentration of dry feeds in the individual trials was varied using different ingredients such as wheat middlings, soybean hull, and ground corn (Hill et al., 2016) and various levels of a single ingredient such as cottonseed or soybean hulls (Hill et al., 2008a,b) or corn distillers dried grains with solubles (Suarez-Mena et al., 2011). Also, physical form (pelleted vs. textured) was confounded with starch concentration in the diets of a few studies (Hill et al., 2016; Dennis et al., 2017; Table 1). Digestion and utilization of starch can be affected by grain characteristics and processing or factors related to other feed components or the animal itself (Firkins et al., 2001; Giuberti et al., 2014). Terré et al. (2015) reported that ground and pelleted starter for calves at $\leq 9 \mathrm{wk}$ of age resulted in lower rumen $\mathrm{pH}$ than textured starter based on whole corn; however, when provided free-choice chopped straw, the calves consuming the same ground and pelleted starter had similar rumen $\mathrm{pH}$ as calves consuming the textured starter based on whole corn. Grain processing or physical form affects rumen $\mathrm{pH}$, which in turn affects calf rumen development, starch digestion, and, consequently, intake and growth.

As previously indicated, all studies used for this analysis were conducted at the same research facility in the same location (i.e., southwest Ohio). Dairy calves with management practices or climates that differ from those in the current study could respond differently to varying starch concentration of dry feed. Further stud- ies using an independent data set should validate the observed relationships of growth performance and digestion by starch concentration of dry feed and should provide information about the potential variation of responses to varying starch concentration due to different management practices in various production settings.

High starch concentration of dry feed would allow better DM digestion of diets, faster growth in BW, and greater frame size of calves from 0 to 16 wk of age. Changing starch amount in a dry feed from 23 to $43 \%$ DM basis (a typical range in the US industry and within the range in this database) was predicted (Table 3 ) to increase ADG and hip width change by 5.8 and $5.0 \%$, respectively, for calves at 0 to $8 \mathrm{wk}$ of age and by 9.6 and $11.2 \%$, respectively, for calves at 8 to 16 wk of age. Indeed, the results in the current study reflect the importance of increasing starch concentrations of dry feed for young dairy calves.

\section{CONCLUSIONS}

Mixed-model analysis of available data collated from the previous studies in our research group showed that starch concentration of dry feed affected growth performance and nutrient digestion of dairy calves. The ADG and hip width change of calves up to $16 \mathrm{wk}$ of age increased linearly with increasing starch concentration of dry feed. The results demonstrate and confirm the importance of high starch concentration of dry feed for young dairy calves. As indicated by meta-regression analysis, growth responses to starch concentration of dry feed are associated with ME concentration in dry feed for calves up to 16 wk of age. Dry feeds fed to young dairy calves should be monitored to ensure that there is high starch content and thus ME concentration sufficient for proper growth.

\section{REFERENCES}

Bateman, H. G., II, T. M. Hill, J. M. Aldrich, R. L. Schlotterbeck, and J. L. Firkins. 2012. Meta-analysis of the effect of initial serum protein concentration and empirical prediction model for growth of neonatal Holstein calves through eight weeks of age. J. Dairy Sci. 95:363-369.

Castells, L., A. Bach, A. Aris, and M. Terré. 2013. Effects of forage provision to young calves on rumen fermentation and development of the gastrointestinal tract. J. Dairy Sci. 96:5226-5236.

Dennis, T. S., F. X. Suarez-Mena, T. M. Hill, J. D. Quigley, and R. L. Schlotterbeck. 2017. Effects of egg yolk inclusion, milk replacer feeding rate, and low-starch (pelleted) or high-starch (texturized) starter on Holstein calf performance through 4 months of age. J. Dairy Sci. 100:8995-9006.

FASS. 2010. Guide for the Care and Use of Agricultural Animals in Research and Teaching. 3rd ed. Fed. Anim. Sci. Soc., Champaign, IL.

Firkins, J. L., M. L. Eastridge, N. R. St-Pierre, and S. M. Noftsger. 2001. Effects of grain variability and processing on starch utilization by lactating dairy cattle. J. Anim. Sci. 79(E-Suppl.):E218E238. 
Fokkink, W. B., T. M. Hill, H. G. Bateman II, J. M. Aldrich, R. L. Schlotterbeck, and A. F. Kertz. 2011. Effect of high- and lowcereal-grain starters on straw intake and rumen development of neonatal Holstein calves. Prof. Anim. Sci. 27:357-364.

Giuberti, G., A. Gallo, F. Masoero, L. F. Ferraretto, P. C. Hoffman, and R. D. Shaver. 2014. Factors affecting starch utilization in large animal food production system: A review. Starke 66:72-90.

Hill, T. M., H. G. Bateman II, J. M. Aldrich, and R. L. Schlotterbeck. 2007. Effects of feeding rate of milk replacers and bedding material for calves in a cold, naturally ventilated nursery. Prof. Anim. Sci. 23:656-664.

Hill, T. M., H. G. Bateman II, J. M. Aldrich, and R. L. Schlotterbeck. 2008a. Effects of the amount of chopped hay or cottonseed hulls in a textured calf starter on young calf performance. J. Dairy Sci. 91:2684-2693.

Hill, T. M., H. G. Bateman II, J. M. Aldrich, and R. L. Schlotterbeck. 2008b. Effects of feeding different carbohydrate sources and amounts to young calves. J. Dairy Sci. 91:3128-3137.

Hill, T. M., H. G. Bateman II, J. M. Aldrich, and R. L. Schlotterbeck. 2010. Roughage amount, source, and processing for diets fed to weaned dairy calves. Prof. Anim. Sci. 26:181-187.

Hill, T. M., H. G. Bateman II, J. M. Aldrich, and R. L. Schlotterbeck. 2011. Comparisons of housing, bedding, and cooling options for dairy calves. J. Dairy Sci. 94:2138-2146.

Hill, T. M., H. G. Bateman II, J. M. Aldrich, and R. L. Schlotterbeck. 2012. High-starch, coarse-grain low-fiber diets maximize growth of weaned dairy calves less than 4 months of age. Prof. Anim. Sci. $28: 325-331$

Hill, T. M., J. D. Quigley, H. G. Bateman II, J. M. Aldrich, and R. L. Schlotterbeck. 2016. Source of carbohydrate and metabolizable lysine and methionine in the diet of recently weaned dairy calves on digestion and growth. J. Dairy Sci. 99:2788-2796.

Kertz, A. F. 2007. Letter to the editor: Pelleted calf starter with straw access can confound results: A comment on Bach et al. (2007). J. Dairy Sci. 90:4924.

Khan, M. A., D. M. Weary, and M. A. G. von Keyserlingk. 2011. Invited review: Effects of milk ration on solid feed intake, weaning, and performance in dairy heifers. J. Dairy Sci. 94:1071-1081.

Kim, Y. H., R. Nagata, N. Ohtani, T. Ichijo, K. Ikuta, and S. Sato. 2016. Effects of dietary forage and calf starter diet on ruminal $\mathrm{pH}$ and bacteria in Holstein calves during weaning transition. Front. Microbiol. 7:1575.

Kosiorowska, A., L. Puggaard, M. S. Hedemann, J. Sehested, S. K. Jensen, N. B. Kristensen, P. Kuropka, K. Marycz, and M. Vester- gaard. 2011. Gastrointestinal development of dairy calves fed low- or high-starch concentrate at two milk allowances. Animal 5:211-219

Kristensen, N. B., J. Sehested, S. K. Jensen, and M. Vestergaard. 2007. Effect of milk allowance on concentrate intake, ruminal environment, and ruminal development in milk-fed Holstein calves. J. Dairy Sci. 90:4346-4355.

Lago, A., S. M. McGuirk, T. B. Bennett, N. B. Cook, and K. V. Nordlund. 2006. Calf respiratory disease and pen microenvironments in naturally ventilated calf barns in winter. J. Dairy Sci. 89:4014-4025.

Lammers, B. P., A. J. Heinrichs, and A. Aydin. 1998. The effect of whey protein concentrate or dried skim milk in milk replacer on calf performance and blood metabolites. J. Dairy Sci. 81:19401945.

Maktabi, H., E. Ghasemi, and M. Khorvash. 2016. Effects of substituting grain with forage or nonforage fiber source on growth performance, rumen fermentation, and chewing activity of dairy calves. Anim. Feed Sci. Technol. 221:70-78.

NRC. 2001. Nutrient Requirements of Dairy Cattle. 7th rev. ed. Natl. Acad. Sci., Washington, DC.

Rabiee, A. R., K. Breinhild, W. Scott, H. M. Golder, E. Block, and I. J. Lean. 2012. Effect of fat additions to diets of dairy cattle on milk production and components: A meta-analysis and metaregression. J. Dairy Sci. 95:3225-3247.

SAS Institute Inc. 2012. Enterprise Guide 5.1. SAS Institute Inc. Cary, NC.

St-Pierre, N. R. 2001. Invited review: Integrating quantitative findings from multiple studies using mixed model methodology. J. Dairy Sci. 84:741-755

Suarez-Mena, F. X., T. M. Hill, A. J. Heinrichs, H. G. Bateman II, J. M. Aldrich, and R. L. Schlotterbeck. 2011. Effects of including corn distillers dried grains with solubles in dairy calf feeds. J. Dairy Sci. 94:3037-3044

Terré, M., L. Castells, M. A. Khan, and A. Bach. 2015. Interaction between the physical form of the starter feed and straw provision on growth performance of Holstein calves. J. Dairy Sci. 98:1101-1109.

Terré, M., E. Pedrals, A. Dalmau, and A. Bach. 2013. What do preweaned and weaned calves need in the diet: A high fiber content or a forage source? J. Dairy Sci. 96:5217-5225.

Zitnan, R., J. Voigt, U. Schönhusen, J. Wegner, M. Kokardová, H. Hagemeister, M. Levkut, S. Kuhla, and A. Sommer. 1998. Influence of dietary concentrate to forage ratio on the development of rumen mucosa in calves. Arch. Tierernahr. 51:279-291. 